\title{
René Char, Lontano dalle nostre ceneri
}

\section{Rosa Galli Pellegrini}

\section{(2) OpenEdition}

\section{Journals}

\section{Edizione digitale}

URL: https://journals.openedition.org/studifrancesi/39792

DOI: 10.4000/studifrancesi.39792

ISSN: 2421-5856

\section{Editore}

Rosenberg \& Sellier

\section{Edizione cartacea}

Data di pubblicazione: 1 décembre 2004

Paginazione: 410

ISSN: 0039-2944

\section{Notizia bibliografica digitale}

Rosa Galli Pellegrini, «René Char, Lontano dalle nostre ceneri», Studi Francesi [Online], 143 (XLVIII | II) | 2004, online dal 30 novembre 2015, consultato il 19 mai 2021. URL: http://journals.openedition.org/ studifrancesi/39792 ; DOI: https://doi.org/10.4000/studifrancesi.39792

Questo documento è stato generato automaticamente il 19 mai 2021.

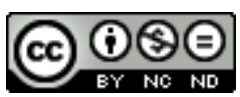

Studi Francesi è distribuita con Licenza Creative Commons Attribuzione - Non commerciale - Non opere derivate 4.0 Internazionale. 


\title{
René Char, Lontano dalle nostre ceneri
}

\author{
Rosa Galli Pellegrini
}

\section{NOTIZIA}

RENÉ CHAR, Lontano dalle nostre ceneri, a cura di Elisa Bricco, Genova, San Marco del Giustiniani, 2003, pp. 54.

1 La curatrice, che è anche la traduttrice della raccolta, introduce il testo con una breve ma esauriente presentazione. Il discorso critico, che vede in quest'opera «una summa poetica» mette in evidenza come queste poesie rappresentino il percorso, storico e umano di Char. Scritte in un arco di tempo molto ampio, dagli esordi del poeta sulla scena della scrittura, alle esperienze surrealiste, all'impegno politico, fino a quelle dell'età avanzata, i versi che raccolgono in finale lo smarrimento del poeta davanti all'esaurirsi del sua vena, ma inviano comunque, secondo l'A., un messaggio di speranza. Elisa Bricco, che si è già cimentata nella traduzione di altri scritti del poeta, mostra anche in questa fatica la sua perfetta padronanza della materia. 